i różnym modelom etyki, tworzonym w sporze z nihilizmem. Zamknięcia konferencji dokonał ks. dr Stanisław Łucarz SJ, dyrektor Instytutu Filozofii Akademii Ignatianum w Krakowie.

ANDRZEJ KOBYLIŃSKI

Instytut Filozofii UKSW, Warszawa

\title{
SPRAWOZDANIE Z MIĘDZYNARODOWEJ KONFERENCJI NAUKOWEJ SOCIO-ETHICAL IDEAS OF CONTEMPORARY RUSSIAN PHILOSOPHY IN THE CONTEXT OF SLAVIC WORLD, TRNAVSKA UNIVERZITA, TRNAWA, 5 MAJA 2015
}

5 maja 2015 roku na Uniwersytecie Trnawskim na Słowacji odbyła się międzynarodowa konferencja naukowa nt. Idee spoteczno-etyczne wspótczesnej filozofii rosyjskiej w kontekście świata stowiańskiego. Sympozjum zostało zorganizowane przez Sekcję Etyki i Filozofii Moralnej Wydziału Filozoficznego Uniwersytetu Trnawskiego. Spotkanie zgromadziło przedstawicieli kilkunastu środowisk uniwersyteckich z Czech, Polski, Rosji i Słowacji. Tegoroczna konferencja stanowiła kolejny etap realizacji trzyletniego grantu VEGA nr 1/0061/14 nt. Socio-ethical themes in contemporary Russian philosophy, realizowanego w latach 2014-2017 przez pracowników naukowych Uniwersytetu Tarnawskiego, przy współpracy m.in. Sekcji Etyki Wydziału Filozofii Chrześcijańskiej Uniwersytetu Kardynała Stefana Wyszyńskiego w Warszawie.

Pierwszym etapem realizacji tego projektu badawczego była międzynarodowa konferencja naukowa nt. Współczesne trendy ,, spoteczno-etyczne" i problem sprawiedliwości w kontekście Europy Środkowej oraz we współczesnej myśli rosyjskiej, która miała miejsce 4 listopada 2014 roku na Uniwersytecie Trnawskim. Sympozjum zostało zorganizowane przez Sekcję Etyki i Filozofii Moralnej Wydziału Filozoficznego Uniwersytetu Trnawskiego oraz Sekcję Etyki Wydziału 
Filozofii Chrześcijańskiej Uniwersytetu Kardynała Stefana Wyszyńskiego w Warszawie. Owocem tej konferencji jest publikacja naukowa, która zawiera 18 artykułów w języku angielskim i słowackim¹.

Miejscem obrad konferencji w dniu 5 maja 2015 roku była historyczna Aula Pazmáneum, znajdująca się w najstarszej części Uniwersytetu Trnawskiego i nosząca imię jego założyciela. Uczestników sympozjum powitała prof. dr hab. Helena Hrehová, kierownik Katedry Etyki i Filozofii Moralnej Wydziału Filozoficznego Uniwersytetu Trnawskiego oraz kierownik grantu VEGA nr 1/0061/14 nt. Socio-ethical themes in contemporary Russian philosophy.

Otwarcia sympozjum dokonał prof. dr hab. Marek Šmid - rektor Uniwersytetu Trnawskiego i pracownik Instytutu Aspektów Prawnych Wolności Religijnej na Wydziale Prawa tej uczelni oraz wykładowca w Papieskim Instytucie Wschodnim w Rzymie. W swoim przemówieniu prof. Šmid zwrócił uwagę na przypadającą w 2015 roku 380. rocznicę powstania Uniwersytetu Trnawskiego z siedzibą w Trnawie.

Obecnie funkcjonująca uczelnia została utworzona de facto 25 marca 1992 roku, ale nawiązuje ona swą misją i nazwą do tradycji dawnego Uniwersytetu Trnawskiego, założonego 12 maja 1635 roku przez Petera Pázmana, arcybiskupa Ostrzyhomia (Esztergom) - węgierskiego miasta nad Dunajem. Niezależność uniwersytetu została potwierdzona 18 października 1635 roku złotą bullą Ferdynanda II Habsburga - króla m.in. Austrii, Czech, Niemiec i Węgier, cesarza Świętego Cesarstwa Rzymskiego. Na początku prowadzenie uniwersytetu zostało powierzone księżom jezuitom. Kilka lat po kasacie tego zakonu, w 1777 roku siedziba Uniwersytetu Trnawskiego została przeniesiona do Budy na Węgrzech. W konsekwencji tej decyzji jego prawnym kontynuatorem jest dzisiaj Uniwersytet im. Loránda Eötvösa w Budapeszcie.

Rektor Marek Šmid podkreślił, że Uniwersytet Trnawski zawsze miał charakter nie tylko lokalny, ale międzynarodowy. W murach tej uczelni, od samego początku jej istnienia, wykładali i studiowali przedstawiciele wielu narodowości, kultur i religii. Prof. Šmid zauważył,

Sociálne idey a spravodlivost', red. H. Hrehová, P. Rusnák, Acta Moralia Tyrnaviensia, t. V, Trnava 2015. 
że obecna konferencja poświęcona filozofii rosyjskiej doskonale wpisuje się w długą tradycję współpracy międzynarodowej Uniwersytetu Trnawskiego.

Uczestników sympozjum powitała także prof. dr hab. Marta Dobrotková, dziekan Wydziału Filozoficznego Uniwersytetu Tarnawskiego, która nawiązała w swoim wystąpieniu do koncepcji narodu i różnych form realizacji idei dobra w filozofii dziejów Johanna Gottfrieda Herdera.

Sesji przedpołudniowej przewodniczył dr Peter Rusnák z Uniwersytetu Trnawskiego. Pierwszy referat nt. Problem relacji celów i środków we współczesnym rosyjskim dyskursie filozoficzno-politycznym wygłosił prof. dr hab. Siergiej Niżnikow z Rosyjskiego Uniwersytetu Przyjaźni Narodów w Moskwie. Prelegent ukazał w swoim wystąpieniu cztery modele odnoszące się do rozumienia moralności w polityce. Pierwszy sposób rozumienia wymiaru moralnego działalności politycznej został wypracowany przez Niccolò Machiavelliego, dla którego dobry cel polityczny usprawiedliwia wykorzystanie także złych środków. Drugi model stanowi swego rodzaju poszerzenie koncepcji Machiavelliego i może być nazwany paradygmatem machiawelicznym. Do jego istoty należy skrajny cynizm - w działalności politycznej są usprawiedliwione wszystkie środki prowadzące do osiągnięcia celu, który wcale nie musi być dobry. W Rosji ten model był realizowany przede wszystkim przez bolszewików.

Trzeci sposób rozumienia wymiaru moralnego działalności politycznej ma charakter humanistyczny i został wypracowany przez Immanuela Kanta. Zdaniem filozofa z Królewca, każdy cel - także w działalności politycznej - powinien być osiągany za pomocą dobrych środków. W kulturze rosyjskiej tego rodzaju myślenie jest typowe dla twórczości Fiodora Dostojewskiego. Jego zdaniem, etyka i polityka wyrastają z wiary w wieczne i transcendentne Dobro. Wiara w Absolutne Dobro jest konieczna dla zachowania moralności w działalności politycznej. Jeśli Boga nie ma, to wszystko wolno. W XX wieku miejsce Absolutnego Dobra zajęli Hitler i Stalin.

Czwarty model odnosi się do idei pacyfistycznych, które wykluczają stosowanie siły i przemocy w działalności politycznej. Zdaniem koryfeuszy tego paradygmatu, polityka nie powinna być kwestią walki i zdobywania władzy, ale przestrzenią kompromisu, dialogu i pokojowego 
rozwiązywania problemów. Największym zwolennikiem totalnego pacyfizmu i zasady całkowitego niesprzeciwiania się złu był w Rosji Lew Tołstoj. Autora Wojny i pokoju bardzo ostro krytykował za jego poglądy pacyfistyczne m.in. znany filozof Iwan Iljin, który wypracował własną doktrynę o sprzeciwianiu się złu siłą. Iljin podkreślał, że zło się rozrasta, jeśli mu się nie sprzeciwiamy. Prelegent z Moskwy stwierdził, że Iljin w swojej działalności poszedł za daleko, ponieważ w pewnym momencie uznał za usprawiedliwioną ograniczoną formę współpracy z bolszewikami. Zdaniem prof. Siergieja Niżnikowa, pacyfistą nie był Mahatma Gandhi, który postulował konieczność aktywnego oporu i sprzeciwu wobec zła. Podobnie sądził Martin Luter King, który twierdził, że zło jest tak silne, ponieważ nie spotyka sprzeciwu ze strony ludzi.

Prof. Niżnikow podkreślił, że polityka potrzebuje uniwersalnych zasad moralnych. Fundamentem obrony moralnego wymiaru polityki powinno być przekonanie o uniwersalnym charakterze moralności. W niezwykle przekonujący sposób pisze o tym Fiodor Dostojewski w Braciach Karamazow. W jednym z fragmentów tego dzieła Dymitr Karamazow wyznaje, że pewnego razu nie spał dwie noce, gdy uświadomił sobie, że ludzie mogą mieć różne rozumienie dobra i zła. Jak ludzie mają dalej żyć - pyta Dymitr Karamazow - jeśli u Rosjan i Chińczyków jest różna moralność?

Drugim referatem w sesji przedpołudniowej było wystąpienie dr. hab. Aleksieja Kozyriewa z Moskiewskiego Państwowego Uniwersytetu im. M. W. Łomonosowa nt. Problem godności człowieka w przeszłości i teraźniejszości myśli rosyjskiej. Prelegent rozpoczął swoją refleksję od ukazania wpływu Platona i Arystotelesa na filozoficzne rozumienie godności ludzkiej, która stanowi fundament praw człowieka. Godność człowieka jest niepodzielna. Nie wolno kwestionować godności żadnej jednostki ludzkiej. Aby respektować godność człowieka, jak uczył Kant, należy traktować innych zawsze jako cel, nigdy jako środek.

Prof. Kozyriew stwierdził, że w myśli rosyjskiej najwięcej o prawach człowieka i godności ludzkiej powiedział Włodzimierz Sołowiow, który ukształtował swoje myślenie w ramach Moskiewskiej Szkoły Prawa. Po ogłoszeniu przez Papieża Leona XIII w 1891 roku encykliki Rerum novarum, Sołowiow podjął w swojej twórczości problem różnych praw przysługujących ludziom. Twierdził, że prawo stanowione 
powinno zawsze wspierać się na dwóch filarach: miłosierdzia i sprawiedliwości. Nie ma sprawiedliwości bez miłosierdzia i miłosierdzia bez sprawiedliwości.

Zdaniem prelegenta z Moskwy, godność człowieka nie jest kwestią ideologii. Jej fundament powinien mieć charakter religijny i transcendentny. W języku religijnym i teologicznym możemy powiedzieć, że godność człowieka jest darem Bożym. Na takie rozumienie godności ludzkiej zwraca obecnie uwagę Cerkiew Prawosławna. Rosyjskie prawosławie nie jest przeciwne prawom człowieka i wartościom europejskim, ale zdecydowanie upomina się o zachowanie ich chrześcijańskich korzeni. W opinii Cerkwi Prawosławnej fundamentem praw człowieka nie może być rewolucja francuska 1789 roku, która - rozpoczynając od haseł równości, wolności i braterstwa - stała się ostatecznie ideologią gilotyny, ale orędzie Ewangelii i chrześcijańska koncepcja osoby ludzkiej. Prof. Kozyriew nie zgodził się z opinią, że w 2014 roku na Majdanie w Kijowie miała miejsce tzw. rewolucja godności. Jego zdaniem, wydarzenia na Majdanie doprowadziły ostatecznie do moralnego poniżenia, przemocy i dezintegracji struktur ukraińskiej władzy państwowej.

Kolejnym wystąpieniem w tej części obrad był referat prof. dr. hab. Heleny Hrehovej z Uniwersytetu Trnawskiego nt. Duchowa integralność człowieka i jej wpływ na idee społeczne we współczesnej filozofii rosyjskiej. Prelegentka z Trnawy zauważyła, że problem duchowej integralności człowieka w filozofii rosyjskiej był przedmiotem wieloletnich badań czeskiego kard. Tomasza Špidlika SJ - wykładowcy patrystyki i teologii duchowości w Papieskim Instytucie Wschodnim i Papieskim Uniwersytecie Gregoriańskim w Rzymie. W odróżnieniu od myśli zachodniej, która akcentowała rolę wielu odrębnych dyscyplin naukowych, zajmujących się interpretacją bytu ludzkiego, filozofia rosyjska w XIX wieku zwracała uwagę na integralną wizję osoby ludzkiej w jej wymiarze humanistyczno-duchowym. Myśliciele rosyjscy podkreślali, że życie społeczne i adekwatna wizja polityki zależą od właściwej koncepcji człowieka. Każdy kryzys polityczny czy ekonomiczny ma swoje najgłębsze przyczyny w kryzysie humanistycznym.

Mówił o tym m.in. rosyjski filozof Mikołaj Bierdiajew w swojej książce O przeznaczeniu człowieka. Zarys etyki paradoksalnej, która zajmuje się osobą ludzką jako istotą moralną. Bierdiajew dążył do 
przezwyciężenia problemów i trudności zawartych w etykach klasycznych. Autor dzieła $O$ przeznaczeniu człowieka zaproponował personalistyczną etykę twórczości, której przesłanie jest dzisiaj szczególnie aktualne także w naszym kręgu kulturowym. Do twórczości Bierdiajewa, ale także do poglądów Dostojewskiego i Tołstoja, nawiązywał rosyjski filozof i socjolog Pitirim Sorokin, który szukał prawdy i dobra w wymiarze transcendentnym i uwrażliwiał ludzi na potrzebę altruizmu. Sorokin sklasyfikował społeczeństwa według ich mentalności kulturowej, która może być ideacyjna (rzeczywistość ma charakter duchowy), odczuciowa (rzeczywistość ma charakter materialny) lub idealistyczna (stanowi syntezę dwóch wyżej wymienionych mentalności). Sorokin zinterpretował współczesną cywilizację zachodnią jako cywilizację odczuciową, oddaną postępowi technicznemu. Prorokował jej przejście w okres schyłkowy, a następnie wyłonienie się nowej ery ideacyjnej lub idealistycznej.

Czwartym wystąpieniem w sesji przedpołudniowej był referat Wolność, dusza i moralność. Refleksja na temat idei etycznych w kontekście języków słowiańskich, który wygłosił ks. prof. dr hab. Ryszard Moń z UKSW w Warszawie. Mówca zauważył, że na rozumienie idei etycznych duży wpływ mają różne uwarunkowania społeczno-kulturowe, które znalazły swoje odbicie w języku. Wolność, dusza czy moralność oznaczają de facto co innego w myśli anglosaskiej lub francuskiej, a co innego w myśleniu słowiańskim. Wśród Słowian należałoby odróżnić rozumienie rosyjskie i pozostałych krajów. Warto by się też dokładniej przyjrzeć podobieństwom i różnicom między myśleniem węgierskim a słowackim czy polskim. Z jednej strony, mamy w tych krajach tradycję wielu lat trwania cesarstwa austro-węgierskiego i to odróżniało Węgrów od Słowaków, z drugiej - nie sposób pominąć wspólnych doświadczeń w ramach bloku socjalistycznego, kiedy te dwa kraje były uzależnione od Związku Radzieckiego.

Abraham Lincoln powiedział kiedyś, że świat nigdy nie posiadał dobrej definicji słowa „wolność”. Zdaniem prof. Monia, trzy czwarte nieszczęść współczesnego człowieka pochodzi ze złego rozumienia wolności, a dokładniej mówiąc, z używania słowa „wolność” w bardzo różnym znaczeniu. Szczególnie widać to w zestawieniu myślenia anglosaskiego i słowiańskiego, ale także polskiego ze słowackim 
czy rosyjskim. Wiąże się to nie tylko z kontekstem użycia, ale także $\mathrm{z}$ odmiennym polem semantycznym, jak i pragmatycznym, uwarunkowanym okolicznościami historyczno-kulturowymi. Warto zatem porównać np. anglosaskie rozumienie wolności z tym, jakie mamy w świecie słowiańskim. Jeśli poddamy głębszej analizie angielskie słowa liberty i freedom, rosyjskie svoboda i volja, słowackie svoboda i polskie wolność, to okaże się, jak wielki wpływ na rozumienie idei etycznych mają różnego rodzaju uwarunkowania historyczne, polityczne i społeczno-kulturowe.

Kolejny referat w tej części obrad wygłosił ks. prof. dr hab. Josef Dolista z Uniwersytetu Karola w Pradze nt. Masarykowa koncepcja Rosji i jej wpływ na filozofię czeska. Tomáš Garrigue Masaryk był w latach 1882-1914 profesorem filozofii na Uniwersytecie Karola w Pradze. Następnie stał się pierwszym i najdłużej urzędującym prezydentem Czechosłowacji. Od lat jest nazywany twórcą niepodległej Czechosłowacji. Jego ojciec był Słowakiem z węgierskiej części Austro-Węgier, natomiast jego matka była Niemką, urodzoną na Morawach. Ponadczasowym przesłaniem myśli filozoficznej Masaryka jest postulat życia w prawdzie oraz sprzeciw wobec rewolucji, która powinna być zastąpiona pokojowym dążeniem państw i narodów do demokracji.

W 1913 roku została opublikowana jego książka Rosja a Europa. Masaryk w swoim dziele poddał analizie różne modele interpretacji bytu ludzkiego obecne w myśli zachodniej i filozofii rosyjskiej. Jego książka została przetłumaczona na wiele języków, m.in. na angielski, francuski, japoński i niemiecki. Max Weber uważał ją za jedną z najważniejszych książek początku XX wieku. Zdaniem prof. Dolisty, Masaryk polemizował z poglądami Kanta, Hume'a czy Marksa, natomiast utożsamiał się z Dostojewskim, Tołstojem i Sołowiowem. Masaryk uważał, że cała Europa potrzebuje wizji człowieka i religii zakorzenionej w bizantyjsko-chrześcijańskiej tradycji Rosji, w której filozofia jest nierozerwalnie związana z religią. Ojciec niepodległości Czechosłowacji zwracał także uwagę na problem nihilizmu w filozofii rosyjskiej, który z choroby Rosji XIX wieku stał się bardzo szybko chorobą całego świata.

Ostatni referat w sesji przedpołudniowej wygłosiła prof. dr hab. Zlatica Plašienková z Uniwersytetu Komeńskiego w Bratysławie nt. Droga rozwoju moralnego w koncepcji etycznej M. O. Łosskiego i jej 
metafizycznych założeń. W 1922 roku Mikołaj Onufrijewicz Łosski, którego matką była Polka a ojcem zrusyfikowany Polak, został wygnany z Rosji przez komunistów. Na zaproszenie Tomáša Masaryka zamieszkał w Czechosłowacji. W latach 1922-1942 mieszkał w Pradze i wykładał na Rosyjskim Uniwersytecie Ludowym, który został założony przez emigrację rosyjską w 1923 roku.

Warto dodać, że po rewolucji bolszewickiej pomoc, jaką otrzymali emigranci rosyjscy od władz czechosłowackich, była większa niż we wszystkich pozostałych krajach razem wziętych. W ciągu kilku lat Praga stała się, po Paryżu i Berlinie, najważniejszym centrum rosyjskiej diaspory. Działało tu ponad sześćdziesiąt rosyjskich organizacji społecznych, kulturalnych i naukowych, ukazywały się rosyjskie dzienniki, tygodniki, szereg pism specjalistycznych. Prężnie działały także rosyjskie wydawnictwa. W Pradze istniały wszystkie typy szkół rosyjskich, działały instytucje naukowe, rosyjskie kluby literackie, teatr.

W 1942 roku Łosski przeniósł się z Pragi do Bratysławy i w latach 1942-1945 wykładał na ówczesnym Uniwersytecie Słowackim w Bratysławie (obecnie Uniwersytet Komeńskiego). Łosski rozwinął w swojej twórczości koncepcję filozoficzną, zwaną przez siebie intuicjonizmem. Dążył do stworzenia całościowego systemu filozoficznego: od ontologii po etykę i aksjologię. W swojej twórczości łączył elementy platonizmu, monadologii Leibniza, intuicjonizmu Bergsona i mistycyzmu Włodzimierza Sołowiowa.

Prelegentka z Bratysławy zauważyła, że Łosski jest najbardziej znanym rosyjskim myślicielem religijnym na Słowacji. Jego system filozoficzny można nazwać noetycznym realizmem intuicyjnym. Łosski wyróżniał trzy rodzaje intuicji: zmysłową, intelektualną i mistyczną. Twierdził, że wszystkie problemy etyczne można rozwiązać na gruncie fundamentu metafizycznego i religijnej wizji świata. Polemizując z etyką autonomiczną Kanta, uważał, że w XX wieku wszyscy potrzebujemy danej przez Boga etyki łaski. Etyka Łosskiego jest jedną z odmian etyki teonomicznej i de facto może być uznana za jedną z form chrześcijańskiej teologii moralnej.

Sesji popołudniowej przewodniczyła dr Katarina Vadiková z Uniwersytetu Trnawskiego. Pierwszy referat w tej części obrad wygłosiła dr hab. Alžbeta Dufferovà z Uniwersytetu Trnawskiego nt. Wpływ 
wewnętrznego świata czlowieka na rzeczywistość zewnętrzna wedtug Walerija Kuwakina. Na początku swojego wystąpienia prelegentka zaprezentowała postać urodzonego w Moskwie w 1939 roku Walerija Aleksandrowicza Kuwakina, który należy obecnie w Rosji do grona najbardziej znanych filozofów i historyków idei.

Zdaniem Kuwakina, każda epoka i każde społeczeństwo mają swoje troski. Nasze czasy są dotknięte przede wszystkim nieokreślonym i przejściowym charakterem wszystkiego, co się dzieje. W przestrzeni tej nieokreśloności nawarstwiają się alarmujące problemy ekonomiczne, ekologiczne i moralne. Co jednak można zrobić w Rosji, ażeby zatrzymać proces degradacji moralnej? Kuwakin twierdzi, że jedyną szansą jest świecki humanizm obywatelski. Dlatego powinno się wprowadzić przedmiot „Humanizm i społeczeństwo obywatelskie” oraz „Współczesny humanizm" w szkołach oraz na wyższych uczelniach całej Rosji. Zdaniem Kuwakina, humanizm to filozofia zdrowego rozsądku. Oparta jest ona na naukowym obrazie świata, na ogólnoludzkich normach moralnych oraz na krytycznym, realistycznym sposobie myślenia.

Drugim referatem w sesji popołudniowej było wystąpienie ks. dr. hab. Andrzeja Kobylińskiego z UKSW w Warszawie nt. Od nihilizmu do komunizmu. W poszukiwaniu filozoficznych korzeni reżimów totalitarnych. Mówca zauważył, że niewyobrażalne barbarzyństwo ubiegłego stulecia dotknęło szczególnie narody Europy Środkowej. Narodziny, trwanie i konsekwencje systemów totalitarnych są dzisiaj przedmiotem wielu badań historycznych, socjologicznych czy politologicznych. Niestety, ciągle brakuje rzetelnej i pogłębionej analizy filozoficznej komunizmu, faszyzmu i narodowego socjalizmu.

Wydaje się, że w filozoficznych badaniach nad totalitaryzmem szczególną rolę może odegrać kategoria nihilizmu. Warto podkreślić, że fenomen nihilizmu zadomowił się w filozofii rosyjskiej kilkadziesiąt lat wcześniej w stosunku do analiz tego zjawiska, zaproponowanych przez Fryderyka Nietzschego. Jeśli dzisiaj pytamy o rozumienie dobra i zła po Auschwitz i Gułagu, to nihilizm jako prawda o rozpadzie trwałego fundamentu moralności i kultury prowadzi nas do głębszego rozumienia mrocznych tajemnic ubiegłego stulecia.

Nihilizm odegrał ważną rolę przy narodzinach trzech wielkich systemów totalitarnych w XX wieku. W pewnym stopniu stworzył on 
warunki umożliwiające ich powstanie. Jednym z pierwszych autorów, pokazujących ten związek już pod koniec lat 30. ubiegłego stulecia, był niemiecki myśliciel Hermann Heller, który jasno wskazał na relatywizm kulturowy Europy początku XX wieku, tzn. kryzys aksjologiczny i upadek przekonań religijnych.

Kontynuację analiz Hellera znajdujemy u niemieckiego filozofa Hermanna Rauschninga. Jego zdaniem, niemiecka rewolucja narodowosocjalistyczna była przede wszystkim szerokim ruchem społecznym i politycznym o charakterze nihilistycznym, a droga do dyktatury była szlakiem mającym tak swój początek, jak i kres w nihilistycznej wizji świata i człowieka. Na związki nihilizmu z systemami totalitarnymi zwraca obecnie uwage m.in. francuski filozof François Dier, włoski intelektualista Gennaro Maria Barbudo czy niemiecki myśliciel Hans Ebeling.

Kolejny referat w tej części obrad wygłosił dr hab. Peter Neznik z Uniwersytetu Pavla Jozefa Šafárika w Koszycach nt. Filozofia słojów drzewnych a współczesne kwestionowanie człowieka. Prelegent stwierdził, że filozofia pomaga nam rozumieć czas, w którym żyjemy. Jego zdaniem, nasza epoka ma charakter postmetafizyczny. Dr hab. Neznik przywołał opinię Hermana Hessego, który twierdził, że człowiek nie czyta Fiodora Dostojewskiego, gdy jest szczęśliwy, ale wówczas, gdy cierpi i doświadcza sytuacji granicznych. Zdaniem mówcy z Koszyc, warto dzisiaj odkryć spuściznę filozoficzną czeskiego idealisty i fenomenologa Jana Patočki, który krytykował Tomáša Masaryka za niewłaściwą interpretację filozofii rosyjskiej.

Czwarty referat w sesji popołudniowej nt. Motywy antropologiczne $w$ filozofii rosyjskiej wygłosił dr hab. Jaromir Feber z Uniwersytetu Technicznego w Ostrawie. Prelegent podkreślił, że specyficznym rysem filozofii rosyjskiej w XIX wieku jest jej charakter chrześcijański. Można powiedzieć, że filozofia uprawiana przez myślicieli rosyjskich w XIX stuleciu była de facto filozofią chrześcijańską. Ważny nurt rosyjskiej filozofii religijnej stanowi idea wszechjedności. Jest ona ważną i ciekawą próbą syntezy świeckiego i religijnego, ale także aksjologicznego i racjonalnego podejścia do filozofii. W koncepcji wszechjedności wszechświat jest kategorią ontologiczną oznaczającą zasadę formy wewnętrznej, doskonałej jedności mnogości, zgodnie z którą wszystkie 
elementy takiej jedności są ze sobą tożsame i tożsame są z całością, jednocześnie nie zlewają się one w nierozróżnialną i zespoloną jedność, ale tworzą konstrukcję szczególną, polifoniczną. W ramach tego nurtu Siemion Frank wypracował argument ontologiczny na istnienie Boga, nawiązujący do dowodu św. Anzelma z Canterbury.

Kolejnym referatem w tej części obrad było wystąpienie dr. Jacka Szczota z Katolickiego Uniwersytetu Lubelskiego nt. Prawo do sprawiedliwości społecznej we współczesnej Polsce. Aspekty społeczne i prawne. Sprawiedliwość społeczna oznacza sprawiedliwy podział dóbr i usług oraz bezstronność organów władzy państwowej w podejściu do wszystkich obywateli. Główny cel sprawiedliwości społecznej polega na tym, aby każdemu oddać to, co się jemu należy jako człowiekowi. W filozofii rosyjskiej XIX wieku głównym uzasadnieniem sprawiedliwości społecznej była koncepcja Bytu Najwyższego. Prelegent z Lublina zauważył, że poglądy niektórych myślicieli rosyjskich XIX wieku (Bakunin, Bierdiajew, Tołstoj) przygotowały grunt pod ideologię marksistowską. Chodzi głównie o traktowanie przez tych intelektualistów państwa i własności jako głównych przyczyn zła w wymiarze społecznym. W konsekwencji twierdzili oni, że trzeba znieść własność i rozwiązać struktury państwowe, aby zmienić świat. Do tych niebezpiecznych i szkodliwych idei nawiązali ideolodzy marksizmu-leninizmu.

Autorem szóstego wystąpienia nt. Od kultury materialistycznej do kultury ducha był dr Peter Grečo z Uniwersytetu Katolickiego w Rużomberku. Prelegent poświęcił swój referat myśli Mikołaja Bierdiajewa i jego ocenie zachodniego liberalizmu. Bierdiajew krytykował zachodni model kulturowy, ale jednocześnie proponował jako lekarstwo na kryzys cywilizacji zachodniej duchową arystokrację, której istota polega na przejściu od kultury materialistycznej do kultury ducha. Do tej koncepcji nawiązuje obecnie niemiecki myśliciel Johann Baptist Metz. Bierdiajew staje się dzisiaj na nowo aktualny, ponieważ jego koncepcja wzywa do rewolucji ducha w kontekście współczesnej kultury masowej i konsumpcyjnej, która zabija jednostkowość i niepowtarzalność osoby ludzkiej.

Kolejny referat wygłosił mgr Ondrej Marchevský z Uniwersytetu Preszowskiego nt. P.Ł. Ławrow - etyczne i praktyczne dylematy filozofii między gabinetem i ulica. Mówca z Preszowa zaprezentował poglądy 
wybitnego matematyka i filozofa rosyjskiego Piotra Ławrowicza Ławrowa, który wyróżnił w swojej twórczości dwa rodzaje dyskursu: uniwersytecki i uliczny. Pierwszy rodzaj dyskursu charakteryzuje się poszukiwaniem prawdy i dociekaniami o charakterze naukowym. Natomiast dyskurs uliczny ma charakter radykalny i rewolucyjny, nie zna kompromisu, charakteryzuje się ekstremizmem i retoryką przemocy.

Ostatnim referatem było wystąpienie mgr. Igora Stryčka z Uniwersytetu Trnawskiego nt. Wplyw ideowy rosyjskiej tradycji filozoficznej i literackiej na myśl A.I. Solżenicyna. Zdaniem prelegenta z Trnawy, dzieło Sołżenicyna wymaga analizy nie tyle literackiej, ile filozoficznej. Tego rodzaju podejście do twórczości autora Archipelagu Gułag jest szczególnie obecne wśród badaczy amerykańskich. Sołżenicyn - stosując w swej twórczości eklektyzm filozoficzny i estetyczny - nie był kontynuatorem żadnego $\mathrm{z}$ wielkich rosyjskich myślicieli, ale pozostawał pod dużym wpływem szczególnie Dostojewskiego i Tołstoja.

W ramach podsumowania konferencji prof. Helena Hrehová przypomniała swoje spotkanie z ks. prof. Tomaszem Špidlikiem SJ w Rzymie w 1985 roku, który zachęcał wówczas - w trakcie dominacji filozofii marksistowskiej we wszystkich państwach Bloku Wschodniego - do studiowania wielkiego bogactwa rosyjskiej tradycji filozoficznej. Następnie ks. prof. Ryszard Moń i ks. dr hab. Andrzej Kobyliński przedstawili główne zarysy nowego międzynarodowego projektu badawczego dotyczącego Mitteleuropy. W nawiązaniu do tych wypowiedzi dr. hab. Aleksiej Kozyriew stwierdził, że tego rodzaju współpraca jest konieczna, ponieważ jako Słowianie czy mieszkańcy Europy Środkowej ciągle wiemy zbyt mało na temat własnych tradycji filozoficznych i kulturowych. 